\title{
Exploring Saudi EFL Student-Teachers' Perceptions of their Teaching Practicum
}

Dr. Mahdi M. A. Ibrahim

Assistant Professor of TEFL

Faculty of Education- Arish University

\section{Abstract}

7 his qualitative study aims to explore the perceptions of Saudi EFL female studentteachers of the main components of their teaching practicum namely; cooperating teachers, university supervisors, host schools and the teaching practicum itself. A total of 44 Saudi female student-teachers voluntarily participated in the study after completing their field training of their teaching practicum in government schools in AlMadinah Al-Munawarah, KSA, the academic year 2017-2018. Data were collected by means of a 60-item Likert-type questionnaire, divided into 4 categories namely; cooperating teachers, university supervisors, host schools \& the teaching practicum itself. Each category included 15 items. The results showed that the student-teachers had positive perceptions of all the components of their teaching practicum. In addition, the participants expressed their appreciation and satisfaction to the whole teaching practicum program in general. Besides, results indicate that cooperating teachers and university supervisors had positive roles in guiding the student teachers toward developing their teaching skills, performance and understanding of their practicum. Finally, it was found out that the constructive feedback provided by university supervisors \& cooperating teachers has a positive impact on the student-teachers' teaching performance.

Keywords: Teaching Practicum, Field Work, StudentTeachers, Cooperating Teachers, University Supervisors, Host Schools.

\section{Introduction \& Background}

Bridging the gap between theory and practice in educational settings is a vital, challenging, and critical task. One of the objectives of student teaching practicum is to offer a suitable context for student-teachers to hone 
their teaching skills and develop their teaching competencies. In addition, student-teacher-trainees are usually sent to nearby government schools to build their teaching performance, put into practice the ideas, skills, techniques, procedures and strategies they have studied in the course of Methods of Teaching in real contexts as an essential educational issue (Smith and Lev-Ari, 2005; AlMekhlafi, 2010; Yan and He, 2010; Al-Seghayer, 2014;Liaw,2014).

The student teaching practicum is a major component of the teacher education programs at the faculties of education. This component has explicit and implicit impact on the student-teachers' present training and future teaching career, (Ishihara, 2005; Anderson, 2007; Farrell, 2007; Alkhawaldeh, 2008; Kiggundu \& Nayimuli, 2009; Tuli \& File, 2009; Nguyen \& Jr. 2010; Yunus, et al., 2010; School of Education, University of Wisconsin- Madison, 2012, Johnson, 2013; Hamaidi et al., 2014).

Relevant literature shows that the teaching practicum provides student-teachers with various-related opportunities and contexts to get their professional development activated. Such opportunities and contexts include creating their own view of their teaching profession, getting a rationale to join the teaching profession, refining their teaching skills, getting the opportunity to have the necessary connections to convert theory to practice with authentic hands-on experience in teaching, allowing insights into new perspectives and increases motivation to continue studying to be able to confront the problems in their classrooms (Korthagen et al., 2006; Rots et al., 2007; Ibrahim, 2008; Yunus et al., 2010; Ulvik \& Smith, 2011; \& Ilin, 2014). 
In fact, there are some contextual factors that affect student- teachers' attitudes, perceptions and performances such as the school context and leadership, school climate, cooperating teachers, university supervisors, previous training of the student teacher trainees and the nature of their interactions with cooperating teachers (Flores \& Day, 2006; Siwatu, 2011).

On the other hand, there are some contextual factors that negatively affect the performance of student-teachers such as unclear roles that student-teachers should play, managing large classes, insufficient curricular and technical resources, inadequate administrative support, few opportunities for collaboration, inadequate time for planning, and excessive procedural demands (Carter \& Cruggs, 2001; Mastropieri, 2001; MacDonald \& Speece, 2001 Conderman \& Stephens, 2000; Kilgore et al., 2000).

In this respect, Al-Mekhlafi (2010) states that the teaching practicum is influenced by some integrated and interrelated factors namely; the duration period of practicum, the university supervisor, the cooperating teacher and the nature of feedback provided to the studentteachers, during and after their presentations.

Observation, application, and reflection are among the critical processes that critically influence distinguished student teacher trainees who tend to become the main backbone of the education system. The importance given to the teaching practicum in teacher training institutions all over the world is always given a great emphasis (Merc, 2010; Yunus et al., 2010; Khan, 2011; Al-Seghayer, 2014).Therefore, no teaching practicum on earth can be fruitful without accomplishing the above mentioned three 
strongly related processes namely; observation, application, and reflection. As an introductory process, student teachers usually start their practicum by observing the practicing teachers at their field experience site as a pre-practicum step. Observation helps them to consider teachers, students, educational discipline and context in a broad manner. In other words, observation is a solid base for both application and reflection. Therefore, student teachers are usually given the opportunity to observe instructors while teaching and are directed to observe a number of activities in their field experience site including starting the teaching, students' interaction, questioning skills, classroom management, the use of eye contact, teacher's voice, motivation techniques, individual, pair/group work, etc. Observations are usually followed by a feedback session about the lessons that were taught.

The various teaching opportunities provided to EFL student- teachers within their teaching practicum settings as well as their reflections have long been addressed in considerable depth (Farrell, 1999, Liou, 2001; Zeyrek, 2001;Bain et al., 2002).

McDonald (2004) suggests that student-teachers should be given the opportunity for self-analysis and reflection in terms of their own teaching. In fact, the main purpose of reflection is to better help student teachers understand and develop their practice. Farrel (2007), believes that one method of encouraging such reflection is fulfilled by encouraging student teachers to identify and maximize their potential in teaching practice. Moreover, reflection, according to Barnes (2013) is "a key piece of the learning cycle during which knowledge is constructed" (p. 38). Furthermore, reflection provides the student-teachers with 
the actual meaning of being teachers to develop their characters, and hence, their identity is developed, their skills are honed, and their knowledge is gained (Harter, 1997; Cuenca, 2010; Dobler, et al., 2009). For these reasons, student-teachers are usually provided with opportunities to reflect on their practicum experience within the context of a faculty-facilitated-discussion group (York University, 2014).

Classroom observations in the student teacher practicum "help student-teachers become more aware of the issues they confront and how they can be resolved to help in narrowing the gap between a teacher's imagined view of teaching and what actually happens" (Richards \& Farrel, 2005, p. 94).

Thus, the student teaching practicum is viewed by numerous studies as a capstone in any teacher preparation program (Ishihara, 2005; Wilson, 2006; Anderson, 2007; Farrell, 2007; Alkhawaldeh, 2008; Kiggundu \& Nayimuli, 2009; Al-Mekhlafi, 2010; Merc, 2010; Khan, 2011; Damar, 2013; Ali \& Al-Adawi, 2013; Johnson, 2013; AlSeghayer, 2014; Ilin, 2014).

The last two decades have witnessed recent calls for reform in education in general, and in student teaching practicum in particular (Jr., 1990;Fullan, 1998; Fan \& Le, 2009; AlSabti, 2012; Elyas \& Richard, 2013; Ahmed, 2014).

One of the key issues that are related to teacher education programs is the understanding of the relationship between the theoretical knowledge possessed by studentteachers and its integration into teaching methods, strategies and skills within their practicum in real 
classroom settings. In fact, the theoretical knowledge and its implications are inseparable two concepts and each one of them does not work without the other (Lampert, 2005; Ball et al., 2008; Ball \& Forzani, 2009; Ambrosetti, 2010; Merc, 2010; Al-Seghayer, 2014).

In 1987, Shulman highlighted the importance of understanding how student-teachers perceive their teaching practicum and develop their knowledge of teaching. A decade later, Angell (1998), indicated that the importance of exploring the perceptions of student-teachers would facilitate their professional development. Student-teaching practicum according to Tuli \& File (1999), Yan \& He, 2010), helps student-teachers discover their activities and creativities, understand the problematic areas in teaching and hence, find solutions to these problems. Hascher et al., (2004) described the teaching practicum as a "protected field for experimentation and socialization within the profession" (p. 626).

Recently, there has been a compelling evidence describing the perceptions and attitudes of EFL pre-service teachers towards their practicum (Le \& White, 2000; Ozgun \& Sen, 2006; Dyatay, 2007; Alkhawaldeh, 2008; Coç, 2011; Johnson, 2013; Hamaidi et al., 2014).

In fact, the success of the student teachers in their teaching practicum experience depends on the role and effectiveness of their mentors (Koerner, 1992; Thibeault, 2003; Ralf, 2005). Mudzielwana (2014: 1834) states "it is therefore important that mentors who work with student teachers in schools are properly prepared for their role".

The purpose of Soyoung's study (2007) was to report on EFL student teachers' experiences of their four-week-long 
student-teaching practicum. Results indicated that the participants had positive attitudes toward their cooperating teachers who provided them with opportunities to be close to their students to understand them well and hence, they could guide some of the trouble making students. However, participants mentioned some challenges related to their practicum such as teaching multi-level classes, classroom management and unengaged cooperating teachers. In addition, some participants reported that some of their cooperating teachers had negative attitudes toward them.

Besides, Al-Mekhlafi's study (2010) investigated the perceptions of a randomly selected sample of 158 UAE EFL fourth year female student-teachers in 20 schools located in the cities of Sharja, Ajman and Fujairah, on the effectiveness of their teaching practicum and practicum supervisors on shaping their practicum experience. Data was collected through a 25-item Likert-type questionnaire. It was found out that the majority of the student-teachers had positive perceptions regarding the effectiveness of the university supervisors and cooperating teachers. In addition, the findings showed that there was a critical need for further research work on the nature of the feedback provided to student-teachers during their practicum and the necessity for creating proper and effective communication channels among the practicum supervisors.

Similarly, Coç (2011) investigated the factors affecting the perceptions of 1842 fourth year Turkish EFL student teachers (1374 females/ 468 males) who were enrolled to the distance B.A Program, about mentor roles according to some factors such as gender, the type of graduation school, the type of cooperating school and the number of student teachers in the supervisory group. The findings did not 
show any differences between both sexes' perceptions of the cooperating teachers' implementation of the mentor roles. It was also found out that the type of graduate school of the student teachers did not affect their perceptions as to the implementation of the mentor responsibilities.

Al Sohbani (2012) explored EFL student teachers' perception toward the student teaching practicum at Ajman University in the United Arab Emirates. A 70- EFL female student-teacher- sample from Ajman and Fujairah campuses participated in the study. The findings showed that the participants have had positive perceptions towards the cooperating teachers, the academic supervisor and the host school.

Lateh \& Muniandy's study (2012) explored the attitudes of student- teachers towards teaching Environmental Education during practicum in Malaysian primary schools. It was indicated that student-teachers had positive attitudes towards their cooperating teachers and the teaching practicum.

A similar study by Qazi et al (2012) explored the role of student teaching practicum in enhancing EFL student teachers' teaching skills. Data analysis showed that the teaching practicum had a significant role in enhancing student teachers' practical classroom skills. Moreover, data obtained from student teachers indicated that the practicum supervisors had a significant role in enhancing their teaching skills namely; lesson planning, implementing lesson planning, using effective teaching aids, classroom management and self-reflection. In addition, the teaching practicum was found out to have a moderate level of effect in terms of developing appropriate teaching aids. Furthermore, it was indicated that the teaching practicum 
had a positive effect in developing student teachers' planning skills and student assessment skills. On the contrary, student teachers were not satisfied with their cooperating teachers who were not encouraging them on their attempts and were always trying to find faults with their work.

Nguyen's study (2013) explored EFL student teachers' perceptions of implementing a peer mentoring model to investigate their psychosocial support from their peers during their practicum. Results showed that the participants of the experimental group reported more psychosocial support in term of listening \& counseling, trusting, and considering one another friends than the control group. In addition, results showed that the participants in the experimental group had more significant and effective perceptions than their peers of the control group in terms of performing psychosocial support functions and practical significance of the results.

Hamaidi et al., (2014) investigated student-teachers' perceptions of practicum practices and challenges. The findings showed that the participants had benefited from the practicum practices and the practicum had positive effects in terms of developing their teaching skills such as the interaction and communication with students and classroom management skills. On the other hand, the challenges that were highlighted by the student-teachers included the lack of guidance provided by practicum university supervisor, the difficulty in communicating with cooperating teachers and the inadequate support provided by them.

Likewise, Ilin (2014) searched the expectations and gains of practicum from the ELT student- teachers' perspectives. In this study, however, the student - teachers 
expressed their disappointments towards their mentors whose academic qualities, their teaching style, management skills, organization of the lesson phases, error correction strategies, their choice of assignments and assessment techniques and excessive use of mother tongue did not match with the picture in their minds in this respect.

Furthermore, recent literature on the challenges faced by EFL student teachers at their pre-service teaching practicum highlights this issue and attracts the attention of educators to find solutions for it, (Merc, 2010; Yunus et al., 2010 ). In fact, Yunus et al., (2010) described the teaching practicum as "the worst nightmare" and pre-service teachers feel "horrific" about it, (p. 723). The reason behind this, according to them, is that the pre-service teachers are new to the profession. Based on the findings of their study, the main challenges faced by the studentteachers included the cultural differences, applying from theory to practice especially on appropriate teaching methodology or strategy, students' discipline as well as the relationship with mentors and supervisors. However, trainees had negative attitudes towards practicum because they received negative attitudes from the administrators towards them.

Besides, Fawzi and Alddabous's study (2019) explored the perceptions of student teachers at Bahrain Teachers College, University of Bahrain of their practicum university academic supervisors' feedback through their practicum. The findings revealed that the participants had gained a clear vision of their practicum and hence, their teaching performance was improved as a result of the clear feedback provided to them by their university supervisors. 
Similarly, a study was conducted by Çapan \& Bedir (2019) to explore EFL student teachers' perceptions of their teaching practicum, peer practicum supervisors and cooperating teachers. Findings reported that practicum led to a clear improvement in the participants' teaching performance, handling students' problems and converting their theoretical knowledge to classroom practices. On the other hand, participants expressed their dissatisfaction with their cooperating teachers who used too traditional supervising methods and tended to impose on them their too traditional methods.

\section{Student Teaching Practicum in the Saudi Context}

The Departments of Curricula and Teaching Methods in the Saudi Faculties of Education, place a great deal of value on school-based experiences for their EFL studentteachers. In cooperation with the Ministry of Education, the student teaching practicum provides EFL student-teachers with real context experiences during their practicum. In this respect, Qazi et al., (2012) asserted that "most teacher education institutes prepare their student teachers for teaching in the real classroom context through 'the practicum' that is a teacher education course unit consisting of both theoretical and practical aspects" (p. 45).

The student teaching practicum provided to studentteachers at the Saudi Faculties of Education is a key experience in early learning teacher preparation programs. It results in student teacher placement in a variety of early learning program setting while working with a mentor teacher, Barnes (2013). Research stressing the positive long lasting effects on later education has focused the attention of education stakeholders on the quality of 
teachers resulting from their teaching practicum (Maxwell et al., 2006; White Book et al., 2009; Burger, 2010).

The student teaching practicum usually extends for an entire academic semester; the final semester of their B.A period of study. EFL student teachers are usually grouped and sent to the assigned schools for field training. They usually spend from 7:00 am till 1:45 pm at these schools. They are also assigned to EFL cooperating teachers and university supervisors in order to enhance their professional development and teaching performance skills. Every EFL student-teacher is expected to be visited by the university supervisor at least four times per semester. Sometimes, an EFL student-teacher is supervised by more than one EFL cooperating teacher. According to the findings of a study conducted by Baniabdelrahman (2004), "it is recommended to offer student teacher trainees the opportunity to work with more than one practicumsupervisor and with more than one supervisor to give student teachers the chance to gain more ideas and experiences". In order to achieve this goal, there should be a specific plan for supervision with the same guidelines, procedures and strategies. However, not all schools of training can offer more than one cooperating teacher because they face a lack of specialized cooperating teachers.

Shortly before the beginning of the practicum, a meeting is usually held at the academic supervisor's office in order to explain to the trainees the objectives, the specific plan for supervision with the same guidelines, procedures and responsibilities of each EFL student-teacher. This meeting, however, allows the trainees to ask questions and make inquiries about their engagement in their teaching practicum and any other issues they might have. 
The teaching practicum is usually a six- hour-credit course that includes a two-hour theoretical part that usually focuses on the methods of teaching, and a fourhour practical one. The evaluation system of the teaching practicum is formative and helps student- teachers recognize their potentials. Communications between EFL student teachers and their supervisors in one hand, and the EFL cooperating teachers on the other, usually focus on pre, during and post teaching performance skills and how they are going to be evaluated.

Sometimes, student-teachers are visited in their classes by other school professionals (e.g. school principal and assistant principal), who tend to observe them and give feedback when needed. At the end of the training day, a short feedback session is usually held in order to discuss the general observations that s/he had made while observing the student-teacher's class. Sometimes, both the cooperating teacher and the university supervisor observe the same lesson taught by the same EFL student-teacher, and hold the same feedback session in order to make it more effective and fruitful.

\section{The Teaching Practicum Context:}

The teaching practicum involves various issues and multiple layers of institutional relationships held by the supervisor of the practicum, the cooperating teacher and students, (Beck \& Kosnik, 2002; LaBoskey \&Richart, 2002; Ishihara, 2005; Damar, 2013). Yuan \& Lee (2014) assured the necessity of "providing EFL student-teachers with an open and supportive environment to maximize their practice and learning during the teaching practicum". The support that should be given to EFL student-teachers, according to Fan \& Le, (2009), includes two categories namely; cultural and language aspects, in order to help 
them overcome their language challenges and cultural differences. To maximize their progress, EFL studentteachers need emotional support and a practicum environment that provide them with safety and confidence (Zeichner, 2002). In other words, student-teachers need to try out their own ideas and practice, their desired teaching methods in a safe context that makes them confident teachers (Ulvik\& Smith, 2011).

Moody (2009) proposed four key elements/components of the teaching practicum context namely; "the emotional and professional support given by the cooperating teacher, the freedom for student teachers to develop their own teaching styles, the provision of specific and constructive feedback, and the approach to assessment". In addition, there are five other components provided by Merc (2010), namely; student teachers, university supervisors, cooperating teachers, students and the educational context.

\section{Phases of the Teaching Practicum within the Saudi Context}

The teaching practicum is undertaken through two main phases; a theoretical phase and a practical one.

\section{Part I: The Theoretical Phase}

This phase usually starts at the very beginning of the last semester of the student-teachers' academic year till the very end of that semester. Student-teachers attend theoretical classes that focus on lesson planning, brain storming skills, presentation skills, classroom management, questioning skills, different approaches to teaching EFL, various techniques to teaching vocabulary, error correction, using visual aids and motivation. This theoretical part is usually given 200 marks and these marks are devoted to trainees' attendance, projects, quizzes, classroom participation and the final written exam. Trainees are usually directed to highlight the problematic areas of their teaching practicum 
in classes in order to reach suitable solutions for such problems.

\section{Part II: The Practical Phase}

This field-based experience is viewed as a significant experience by both the student-teachers as well as their cooperating teachers in EFL teacher education programs (Walsh \& Elmslie, 2005; Qazi et al., 2012; Cruickshank \& Westbrook, 2013; Dang, 2013). This phase is undertaken through the following three stages:

\section{The Registration Stage}

At the very beginning of the last semester of the final academic year, student-teachers fill out a practicum application where they provide their personal information which usually includes their names, date and place of birth, level of study, contact number and email address. They usually select their desired schools from a list that includes the names of all cooperating schools that belong to the Ministry of Education within the same city where the university is located. A few days later, student-teachers are grouped and given the names of the assigned schools and a letter from the teaching practicum unit that belongs to the Department of Curricula \& Methods of Teaching at the Faculty of Education. They submit the letter to the cooperating school principal and get registered at that particular cooperating school. They, then, become ready to start the second phase of their practicum namely; the observation stage.

\section{The Observation Stage}

Once student-teachers are registered at the cooperating school, they are oriented to the cooperating school environment and the instructional activities, schedule, the computer lab, the resources center, the disciplinary procedures, school system and management, teachers and 
classes. They are also assigned to cooperating teachers who attend their classes and observe them while teaching. The cooperating teachers are always specialized in English Language Teaching (ELT). They use an observation checklist which is usually sent to them by the training unit at the University. The checklist includes some of the basic teaching skills such as the establishment of a suitable learning environment, classroom management, questioning techniques, lesson presentation, time management, verbal/ nonverbal communication, reinforcement,using technology and classroom assessment A feedback session is usually held at the end of the school day. The feedback usually focuses on what had been observed in classes and the student-teachers are given the opportunity to ask questions about issues they have in minds and feel free to express their ideas about what they like and dislike about the consequences of that training day. The observation stage usually lasts for two weeks. (Please see appendices 1, 2 \& 3 for the observation checklist used by student teacher trainees, academic university supervisors, school principals and cooperating teachers).

\section{The Actual Teaching Stage}

This is the most important stage because studentteachers start to play the roles of the actual practicing teachers and hence, these roles are various, critical and challenging. In this context, Nguyen (2013) was with the opinion that "most student-teachers feel stressed when facing the realities of teaching and find it difficult to handle the situation in classroom teaching". Sleep (2009) mentions a number of these responsibilities such as "deciding the time necessary for each step, choosing related tasks, examples, models and materials, keeping eyes on the learning goals, managing individual student behavior, maintaining a productive learning environment, 
interpreting students' work, crafting responses, assessing and steering all of this towards each students' growth".

As soon as student-teachers get acquainted to the school system, they are assigned to specific classes, get their schedule, and substitute the actual EFL teachers and start teaching the English language in real classroom experiences under the supervision of school cooperating teachers and the university practicum supervisors. They have the full responsibility of their classes in terms of teaching English, giving quizzes, tests, correcting assignments, exam invigilation and other practicum-related works. Sometimes, they have the opportunity to voluntarily substitute other EFL teachers to have more teaching opportunities. EFL student-teachers usually use emails to exchange information with the cooperating teachers about urgent issues that are related to their teaching practicum such as the schedule, changes that might occur on it, seeking help on how to teach a specific point and so on. In this context, Le \& White (2000) stated that "the use of email to discuss issues related to the practicum is expanding to involve university lecturers and teachers emailing directly for the development of the practicum".

The EFL student-teachers often have evening courses at the university after they finish their training days at schools. This stage usually lasts until the end of the last week before the university final examinations start. Very often, the university supervisor and the cooperating teacher share a feedback session that focuses on student-teachers practicum related issues.

By the end of their field training of their teaching practicum, student-teachers are evaluated by their practicum supervisors, school principals and cooperating teachers. The total grade of the practicum is 600 marks. 
200 marks are assigned to the theoretical part where students sit for the final examination. 320 marks are assigned to the university academic supervisor \& 80 marks are assigned to the school principal and cooperating teachers.

The evaluation system of the teaching practicum is clarified in the table below:

Table (1): The evaluation system within the teaching practicum.

\begin{tabular}{|l|l|}
\hline \multicolumn{1}{|c|}{ Item } & Marks \\
\hline Theoretical Part & $\mathbf{2 0 0}$ \\
\hline Practicum Supervisor & $\mathbf{3 2 0}$ \\
\hline $\begin{array}{l}\text { School Principal/cooperating } \\
\text { teacher }\end{array}$ & $\mathbf{8 0}$ \\
\hline Total & $\mathbf{6 0 0}$ \\
\hline
\end{tabular}

The teaching practicum phases in the Saudi context are shown in the chart below:

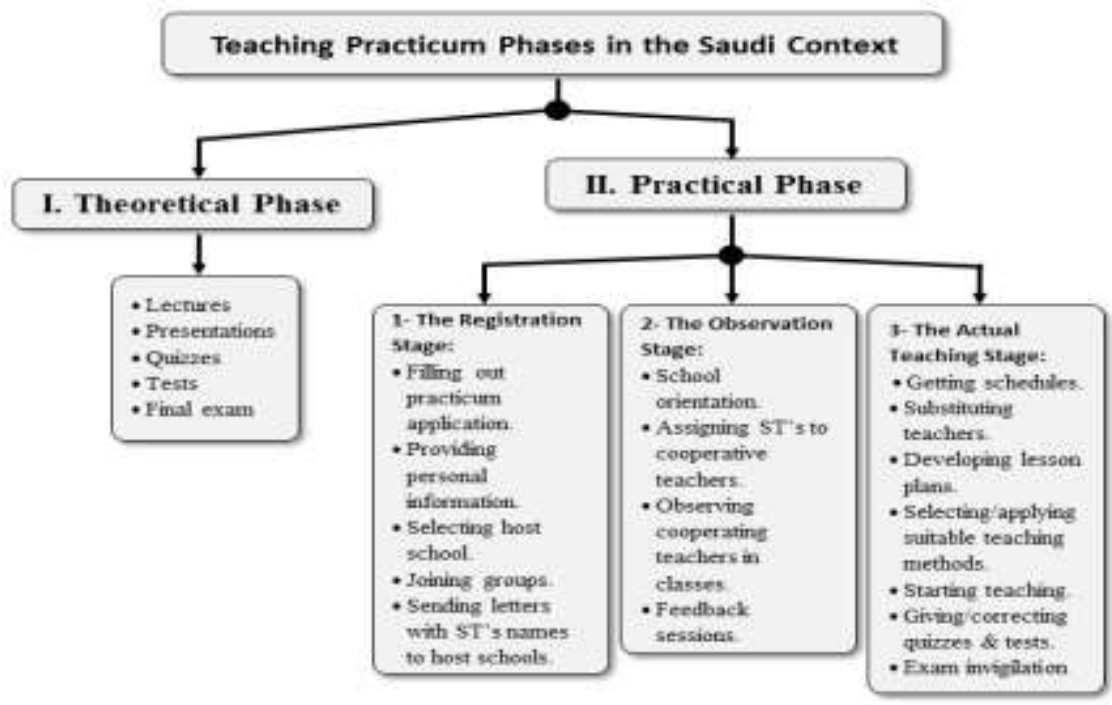

\section{Statement of the Problem}

Saudi EFL female student-teachers are always sent to practice teaching for one complete semester in real classroom contexts at government schools. This is an 
important issue that has been highlighted by many studies (Al-Mekhlafi, 2010; Lateh \& Muniandy , 2013; Dweikat, 2013; Hamaidi et al., 2014). Furthermore, knowing the perceptions of EFL student teachers of their practicum context is important in understanding teachers' thought process, instructional practice and learning to teach (Zheng, 2009). Therefore, the present study tried to explore the Saudi EFL female student teachers' perceptions of their cooperating teachers, university supervisors, host schools, and the teaching practicum in general.

\section{Questions of the Study}

The present study seeks to answer the following questions:

1. How do Saudi EFL female student teachers perceive their practicum cooperating teachers?

2. How do Saudi EFL female student teachers perceive their practicum academic supervisors?

3. How do Saudi EFL female student teachers perceive their host school?

4. How do Saudi EFL female student teachers perceive their teaching practicum in general?

5. What remarks and suggestions would Saudi EFL female student teachers make in terms of developing their teaching practicum?

\section{Significance of the Study}

The significance of the present study emerged from the significance of this particular teaching practicum program, its key role in honing the prospective teachers' teaching skills, preparing them for teaching the English language in an extensively changeable age that is full of various education-related challenges. Furthermore, the quality of 
the EFL student-teachers is considered as one part of the same quality product of the teaching practicum and the same circumstances and events happening around it. In addition, the results of this study might draw the attention of all education stakeholders to the challenges and issues faced by EFL student teachers and hinder their performance so that they might minimize such challenges and hence, the training process becomes better applied and the practicum challenges are minimized.

\section{Purpose of the Study}

The purpose of this exploratory investigation is to find out the perceptions of Saudi EFL female student teachers within their teaching practicum context. The goal is to gain insight into this complex issue from the EFL studentteachers' perspective and to highlight the factors they perceive as having an impact on their teaching performance.

\section{Delimitations of the Study}

The present study was delimited to a 44 Saudi EFL female student teachers who were enrolled in the English Department at the Faculty of Education, Taibah University in Al-Madina Al-Munawarah during the second semester of the academic year 2017-2018. In addition, the participants' perceptions were delimited to four practicum components namely; the cooperating teachers, university supervisors, host schools and the teaching practicum in general.

\section{Definitions of Terms}

\section{Teaching Practicum}

Hamaidi et al., (2014) defined this term as "a program that provides a meaningful field experience offered by the Faculty of Educationa. It is applied as a part of teacher 
preparation program", (p. 196). In this study, the term practicum is defined as a six-hour credit course provided to EFL student-teachers to practice teaching in real contexts at schools that belong to the Ministry of Education with the purpose of enhancing their professional development for their future profession as teachers of English as a foreign language. In some countries the term "practicum" is known as "teaching practice", while in other countries it is known as "practical education".

\section{EFL Student-Teachers}

The students enrolled in the English Departments at the Faculties of Education who join the " teaching practicum" for one final semester of their last year of their university academic study. They are also called student-teacher trainees \& prospective teachers.

\section{Host Schools}

The schools in which the EFL student-teachers practice teaching within their practicum. These schools are usually government ones, and they belong to the Saudi Ministry of Education. Sometimes, they are called cooperating schools.

\section{Cooperating Teachers}

The EFL teachers, who supervise the EFL studentteachers together with the university supervisors during the practicum, give them feedback and evaluate them at the end of their practicum.

\section{Methodology}

\section{Population and Sample}

The target population of this study consisted of all EFL female student teachers enrolled in the fourth year, English Department, Faculty of Education, Taibah University in Al-Madinah Al-Munawarah Campus, at the end of the second semester of the academic year 2017-2018. The total number of the population was 73 female students. However, 29 participants were excluded from the statistical 
analysis due to their participation in the reliability of the questionnaire and hence, the total number of the study sample that responded to the questionnaire items was 44 EFL female student teachers.

\section{Design of the Study}

This descriptive study was conducted to explore Saudi EFL female student teachers' perceptions of four components of their teaching practicum namely; cooperating teachers, university academic/ university supervisors, host schools and their practicum in general. A descriptive method is usually appropriate for educational research that explores students' perceptions, ideas, attitudes and point of view, Gall, Borg and Gall (1996).

\section{Instrument of the Study}

To achieve the aims of this research, a-60-item questionnaire was designed by the researcher based on the literature review. In designing the questionnaire, reference was made to previous research on different roles played by cooperating teachers, academic supervisors, host schools and practicum related issues.

\section{Format of the Questionnaire}

The questionnaire was divided into four categories namely; cooperating teachers, university academic supervisors, host schools and the teaching practicum in general. The questionnaire follows Likert Scale strongly agree (5), agree (4), uncertain (3), disagree (2) \& strongly disagree (1). Each of the questionnaire dimensions included 15 items with the total number of the four dimensions 60 items.

\section{Validity \& Reliability of the Questionnaire}

In order to check its correctness \& appropriateness for administration, the questionnaire in its tentative format was validated by 10 university staff members in the field of TEFL. Based on the feedback provided by the jurors, some 
corrections were made to some of the questionnaire items and was valid, easy to understand and suitable to be administered to a study sample to ensure its reliability.

To measure the reliability of the questionnaire, "testretest method" was used. When the questionnaire was valid and ready to be used, it was administered to a 29-studentteacher-sample. Two weeks later, the questionnaire was reapplied to the same sample and the participants' responses were almost as the same as the first application and hence, the questionnaire in its final version was reliable and ready to be submitted to the research sample. (Please see appendix B for the final version of the questionnaire).

\section{Administration of the Questionnaire}

The questionnaire was emailed to all Saudi EFL female student teachers $(\mathrm{N}=73)$ after they passed the final examination of their fourth and final year of their study. The participants were kindly requested to indicate their perceptions of their cooperating teachers, university supervisors, the host school and the practicum in general by marking the appropriate box in the questionnaire to indicate their responses to each of the questionnaire items. It took two months to get all the questionnaires back with the participants' responses.

\section{Findings \& Discussion}

The purpose of this study was to explore the Saudi EFL Female student-teachers' perceptions of their cooperating teachers, university supervisors, host schools and the practicum in general.

After the questionnaire was administered to the study sample; duplicates account; monitoring of all grades in the selection of the five choices, the questions were answered. 


\section{The Answer of the First Question:}

1. How do Saudi EFL female student-teachers perceive the practicum cooperating teachers?

Table (2) illustrates Means and standard deviations of the items that belong to the first part "practicum cooperating teachers" as follows:

Table 2. Means and standard deviations and ranks for the first dimension (The Cooperating Teacher) of the study questionnaire.

\begin{tabular}{|c|c|c|c|c|c|}
\hline No & Statement & 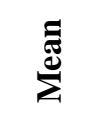 & $\vec{E}$ & 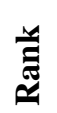 & 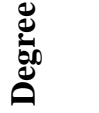 \\
\hline 1 & $\begin{array}{l}\text { Introduced me to colleagues; school principal, } \\
\text { teachers \& coordinator }\end{array}$ & 3.84 & 1.02 & 3 & Large \\
\hline 2 & $\begin{array}{l}\text { Provided me with a space for personal } \\
\text { belongings. }\end{array}$ & 3.63 & 1.181 & 8 & Large \\
\hline 3 & $\begin{array}{l}\text { Planned, in advance, the general structure of } \\
\text { the teaching practicum. }\end{array}$ & 3.49 & 1.16 & 11 & Large \\
\hline 4 & $\begin{array}{l}\text { Encouraged me to learn students' names as } \\
\text { soon as possible. }\end{array}$ & 3.95 & 1.09 & 1 & Large \\
\hline 5 & $\begin{array}{l}\text { Acquainted me with materials, timetable, } \\
\text { books, teaching aids and available } \\
\text { technology (data show, overhead projector, } \\
\text { etc.). }\end{array}$ & 3.95 & 1.19 & 1 & Large \\
\hline 6 & $\begin{array}{l}\text { Discussed ways of contact with me outside } \\
\text { school hours. (i.e., exchange phone numbers, } \\
\text { email addresses, Facebook and Whats App. ) }\end{array}$ & 3.72 & 1.20 & 5 & Large \\
\hline 7 & Helped me prepare teaching activities. & 3.53 & 1.098 & 10 & Large \\
\hline 8 & Assisted me to prepare suitable lesson plans. & 3.58 & 1.22 & 9 & Large \\
\hline 9 & Assisted me to design suitable quizzes/tests & 3.39 & 1.24 & 14 & Mid \\
\hline 10 & Checked my lesson plans periodically & 3.37 & 1.2 & 15 & Mid \\
\hline 11 & $\begin{array}{l}\text { Provided me with detailed constructive } \\
\text { feedback both in written and oral forms. }\end{array}$ & 3.49 & 1.20 & 11 & Large \\
\hline 12 & $\begin{array}{l}\text { Gave me feedback right after watching me } \\
\text { teaching }\end{array}$ & 3.79 & 1.12 & 4 & Large \\
\hline 13 & $\begin{array}{l}\text { Encouraged my personal growth; } \\
\text { appearance and mannerisms, speech, voice } \\
\text { and acceptance of evaluations and } \\
\text { suggestions. }\end{array}$ & 3.7 & 1.1 & 6 & Large \\
\hline 14 & $\begin{array}{l}\text { Let his/her students know about the teaching } \\
\text { practicum. ( my status, roles \& } \\
\text { responsibilities). }\end{array}$ & 3.49 & 1.16 & 11 & Large \\
\hline 15 & $\begin{array}{l}\text { Articulated the rules, practices and activities } \\
\text { of the school. }\end{array}$ & 3.65 & 1.02 & 7 & Large \\
\hline \multicolumn{2}{|r|}{ Total } & $\mathbf{5 4 . 5 8}$ & 11.46 & & Large \\
\hline
\end{tabular}


Data analysis of table 2 shows that the Saudi EFL female student teachers' perception of their cooperating teachers reached a large average level of 54.58 with an 11.46 standard deviation. The items 1 to 11 proved to be large with means ranging between 3.37 and 3.95 as well as a standard deviation ranging between 1.02 and 1.22. In addition, the items 14 and 15 revealed a medium range with a means floating between 3.37 and 3.39 and two standard deviations between 1.2 and 1.24

This can indicate that the cooperating teachers played positive, encouraging roles to help student teachers to enhance their practicum skills such as providing them with positive and constructive feedback, helping them with their lesson plans, and encouraging their social and academic growth. In addition, the results of this study are consistent with the results of Lateh \& Muniandy's study (2012), Al Sohbani (2012), Al-Mekhlafi (2010), Soyoung (2007) in terms of the fact that student teachers had positive perceptions of their cooperating teachers, providing student teachers with opportunities to be close to their students and understand them well.

On the contrary, the results of this study are not in line with those of Qazi et al (2012) which indicated that student teachers were not satisfied with their cooperating teachers who were not encouraging them on their attempts and were always trying to find faults with their work. In addition, the results of this study are not consistent with the results of Capan \& Bedir (2014) which indicated that the cooperating teachers used traditional supervisory techniques and imposed their own traditional teaching methods on the student teachers. 


\section{The Answer of the Second Question:}

2. How do Saudi EFL student-teachers perceive the practicum academic supervisors?

Table (3) illustrates Means and standard deviations of the phrases that belong to the second part "practicum academic supervisors" as follows:

Table 3. Means, standard deviations and ranks for second dimension (The University/Academic Supervisor) of the study questionnaire.

\begin{tabular}{|c|c|c|c|c|c|}
\hline No & Statement & 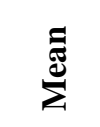 & $\vec{D}$ & 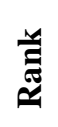 & 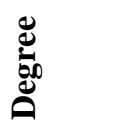 \\
\hline 16 & $\begin{array}{l}\text { The University/Academic Supervisor } \\
\text { Defined the scope of the practicum to me. }\end{array}$ & 3.86 & 0.91 & 10 & Large \\
\hline 17 & $\begin{array}{l}\text { Assigned practicum tasks required for the } \\
\text { course }\end{array}$ & 3.95 & 0.65 & 7 & Large \\
\hline 18 & $\begin{array}{c}\text { Offered constructive feedback on my } \\
\text { teaching performance. }\end{array}$ & 4.23 & 0.9 & 1 & $\begin{array}{l}\text { Very } \\
\text { Large }\end{array}$ \\
\hline 19 & Gave me a chance to revise my lesson plans. & 4.14 & 0.91 & 4 & Large \\
\hline 20 & $\begin{array}{c}\text { Showed me how to relate theory to practice } \\
\text { in teaching. }\end{array}$ & 3.81 & 1.1 & 11 & Large \\
\hline 21 & Was available when needed. & 4.14 & 0.97 & 4 & Large \\
\hline 22 & $\begin{array}{l}\text { Provided me with references needed for } \\
\text { practicum. }\end{array}$ & 3.79 & 1.19 & 13 & Large \\
\hline 23 & $\begin{array}{c}\text { Motivated me to use creative strategies of } \\
\text { teaching. }\end{array}$ & 4.23 & 0.81 & 1 & $\begin{array}{l}\text { Very } \\
\text { Large }\end{array}$ \\
\hline 24 & $\begin{array}{c}\text { Held regular meetings to discuss my } \\
\text { progress in teaching. }\end{array}$ & 3.60 & 1.16 & 14 & Large \\
\hline 25 & $\begin{array}{c}\text { Supported the student/cooperating teacher } \\
\text { relationship. }\end{array}$ & 3.95 & 0.9 & 7 & Large \\
\hline 26 & $\begin{array}{c}\text { Provided experiences consistent with the } \\
\text { learning objectives. }\end{array}$ & 3.93 & 0.83 & 9 & Large \\
\hline 27 & $\begin{array}{l}\text { Helped me to feel secure during the } \\
\text { practicum. }\end{array}$ & 4.14 & 0.91 & 4 & Large \\
\hline 28 & $\begin{array}{c}\text { Made appropriate referrals to school and/or } \\
\text { community resources. }\end{array}$ & 3.81 & 0.96 & 11 & Large \\
\hline 29 & Was a good listener/ attentive. & 4.21 & 0.77 & 3 & $\begin{array}{l}\text { Very } \\
\text { Large } \\
\end{array}$ \\
\hline & Total & 55.81 & 9.49 & & Large \\
\hline
\end{tabular}


Data analysis of table 3 shows that the Saudi EFL female student teachers' perception of their academic university supervisors reached a large average level of 55.81 with a 9.49 standard deviation. The items 1 to 3 proved to be very large with means ranging between 4.21 and 4.23 as well as a standard deviation ranging between 0.77 and 0.9 . In addition, the eleven items 4 to 14 revealed a high range with a means floating between 3.6 and 4.14 and a standard deviation between 0.65 and 1.19.

This can show that academic university supervisors shared their experiences with the student teachers in terms of providing them with constructive feedback, listening to them tentatively, providing them with references related to the practicum, motivating them to implement and create strategies needed for their teaching practicum and were available when needed.

The results of this study are consistent with those studies of Al-Mekhlafi (2010), Al-Sobhani (2012), Qazi et al (2012) and Hamaidi et al., (2014) in terms of having positive perceptions of their academic supervisors who tended to share their experiences that had direct positive results in terms of developing their teaching skills. On the other hand, the results of this study are not consistent with those of Yunus et al (2010) in terms of the negative attitudes that were gained by the student teachers toward their supervisors who did not provide them with any expected constructive feedback.

\section{The Answer of the Third Question:}

3. How do Saudi EFL student-teachers perceive the practicum host schools?

Table (4) illustrates Means and standard deviations of the phrases that belong to the third part "the host school" as follows: 
Table 4. Means, standard deviations and ranks for third dimension (The Host School) of the study questionnaire.

\begin{tabular}{|c|c|c|c|c|c|}
\hline No & Statement & 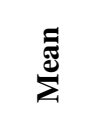 & $\frac{5}{\omega}$ & 范 & 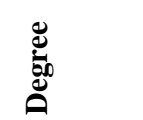 \\
\hline 30 & The general school atmosphere was comfortable. & 3.53 & 1.14 & 7 & Large \\
\hline 31 & All EFL teachers were cooperative \& helpful.. & 3.63 & 1.2 & 6 & Large \\
\hline 32 & $\begin{array}{l}\text { All teaching aids (computers, printers, markers, } \\
\text { erasers, books, visual s) were available . }\end{array}$ & 2.65 & 1.45 & 15 & Moderate \\
\hline 33 & I made use of observing EFL teachers. & 3.91 & 0.68 & 2 & Large \\
\hline 34 & I made use of school library. & 2.7 & 1.24 & 14 & Moderate \\
\hline 35 & School schedule was flexible. & 3.28 & 1.2 & 12 & Moderate \\
\hline 36 & I was encouraged to use technology in teaching. & 3.49 & 1.16 & 9 & Large \\
\hline 37 & The number of students in classes was very big. & 3.77 & 1.39 & 4 & Large \\
\hline 38 & The host school was easy to reach. & 3.86 & 0.97 & 3 & Large \\
\hline 39 & I felt welcomed in the host school. & 4.07 & $\mathbf{0 . 8 8}$ & 1 & Large \\
\hline 40 & $\begin{array}{l}\text { The majority of students were cooperative, } \\
\text { obedient \& polite. }\end{array}$ & 3.4 & 1.07 & 11 & Large \\
\hline 41 & $\begin{array}{l}\text { I was given an opportunity to substitute other } \\
\text { teachers. }\end{array}$ & 3.53 & 1.18 & 7 & Large \\
\hline 42 & The host school principal was easily reachable. & 3.77 & 1.15 & 4 & Large \\
\hline 43 & $\begin{array}{l}\text { The host school facilities/ equipment (library- } \\
\text { meeting room- computer lab- materials) were } \\
\text { accessible. }\end{array}$ & 3.09 & 1.25 & 13 & Moderate \\
\hline 44 & $\begin{array}{l}\text { It was easy to adapt with the host school } \\
\text { members (academic \& administrative personnel) }\end{array}$ & 3.49 & 1.03 & 9 & Large \\
\hline & Total & 52.16 & 9.46 & & Large \\
\hline
\end{tabular}

Data analysis of table 4 shows that the Saudi EFL student teachers' perception of their host schools reached a large average level of 52.168 with a 9.46 standard deviation. The items 1 to 11 proved to be large with means ranging between 3.4 and 4.07 as well as a standard deviation ranging between 0.68 and 1.39. In addition, the 4 items 12 to 15 revealed a medium range with a means floating between 2.65 and 3.28 and standard deviations 
between 1.2 and 1.45. This explained that the host school provided the student teachers with the facilities and positive context that are needed for creating a fruitful training context and hence, they had positive perceptions of the host schools. In addition, the host schools were found to be easy to reach and hence, this particular point resulted in gaining positive attitudes toward the host school. The results of this study are consistent with the results of $\mathrm{Al}$ Sobhani (2013), Al Mekhlafi (2010) and Lateh \& Muniandy (2013) in terms of the cooperation shown by the personnel and students at the host schools which resulted in positive attitudes from the student teachers side.

\section{The Answer of the Fourth}

\section{Question:}

4. How do Saudi EFL student-teachers perceive their teaching practicum in general?

Table (5) illustrates Means and standard deviations of the phrases that belong to the fourth part " teaching practicum in general" as follows:

Data analysis of table 5 shows that the Saudi EFL female student teachers' practicum in general reached a large average level of 59.98 with a 7.47 standard deviation. The items 1 to 5 proved to be very large with means ranging between 4.37 and 4.47 as well as standard deviations ranging between 0.73 and 1.03. In addition, the seven items 6 to 12 revealed a large range with a means ranging between 3.63 and 4.12 with a 0.94 and 1.13 standard deviation. Moreover, the two items 13 and 14 reached a medium average level of 2.77 with 1.25 and 1.27 standard deviations. Furthermore, the items 15 and 16 revealed a low range with a means ranging between 2.49 and 2.56 and two standard deviations between 1.28 and 1.44 . 
Table 5. Means, standard deviations and ranks for fourth dimension (The Practicum in General) of the study questionnaire.

\begin{tabular}{|c|c|c|c|c|c|}
\hline No & Statement & 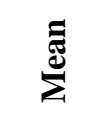 & $\bar{\sigma}$ & 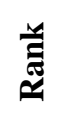 & 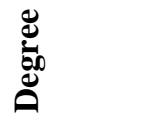 \\
\hline 45 & $\begin{array}{l}\text { The registration in the practicum was } \\
\text { easy \& accessible. }\end{array}$ & 3.74 & 1.04 & 11 & Large \\
\hline 46 & $\begin{array}{l}\text { The objectives of the practicum were } \\
\text { clear. }\end{array}$ & 3.91 & 1.13 & 9 & Large \\
\hline 47 & $\begin{array}{l}\text { There should be no university lectures on } \\
\text { the same days of practicum. }\end{array}$ & 4.42 & 1.03 & 3 & $\begin{array}{l}\text { Very } \\
\text { Large }\end{array}$ \\
\hline 48 & $\begin{array}{l}\text { I made use of meeting new people with } \\
\text { different personalities during the } \\
\text { practicum. }\end{array}$ & 4.37 & 0.76 & 5 & $\begin{array}{l}\text { Very } \\
\text { Large }\end{array}$ \\
\hline 49 & $\begin{array}{l}\text { The practicum period (one semester) is } \\
\text { not enough. }\end{array}$ & 2.49 & 1.44 & 16 & Low \\
\hline 50 & $\begin{array}{l}\begin{array}{l}\text { Dealing with students made me feel } \\
\text { happy. }\end{array} \\
\end{array}$ & 4.09 & 1.06 & 7 & Large \\
\hline 51 & The host school was difficult to reach. & 2.77 & 1.25 & 13 & Moderate \\
\hline 52 & $\begin{array}{l}\text { We should } \begin{array}{c}\text { be } \\
\text { provided }\end{array} \\
\text { transportations } \\
\text { to the host school. }\end{array}$ & 3.63 & 1.11 & 12 & Large \\
\hline 53 & $\begin{array}{l}\text { There is a gap between what we learn at } \\
\text { the university (theory) and what we } \\
\text { practice in practicum. }\end{array}$ & 3.95 & 1.13 & 8 & Large \\
\hline 54 & $\begin{array}{l}\text { Constructive feedback provided by } \\
\text { mentors helped me enhance my teaching } \\
\text { skills. }\end{array}$ & 3.86 & 0.94 & 10 & Large \\
\hline 55 & $\begin{array}{l}\text { I was allowed to access the host school } \\
\text { internet service. }\end{array}$ & 2.77 & 1.27 & 13 & Moderate \\
\hline 56 & $\begin{array}{l}\text { The number of classes I taught was not } \\
\text { enough. }\end{array}$ & 2.56 & 1.28 & 15 & Low \\
\hline 57 & $\begin{array}{lcc}\text { Teaching different } & \text { student } & \text { levels } \\
\text { increased my teaching experience. } & \\
\end{array}$ & 4.12 & 1.03 & 6 & Large \\
\hline 58 & $\begin{array}{l}\text { The practicum gave me the sense of } \\
\text { responsibility \& commitment. }\end{array}$ & 4.4 & 0.73 & 4 & $\begin{array}{l}\text { Very } \\
\text { Large }\end{array}$ \\
\hline 59 & $\begin{array}{l}\text { The practicum helped me to be prepared } \\
\text { for the future teaching job. }\end{array}$ & 4.44 & 0.77 & 2 & $\begin{array}{l}\text { Very } \\
\text { Large }\end{array}$ \\
\hline 60 & $\begin{array}{l}\text { The practicum let me know about my } \\
\text { teaching points of strength } \& \text { weakness. }\end{array}$ & 4.47 & 0.74 & 1 & $\begin{array}{l}\text { Very } \\
\text { Large }\end{array}$ \\
\hline & Total & 59.98 & 7.46 & & Large \\
\hline
\end{tabular}


This can show that the general contest of the practicum revealed the points of strength and weakness of the student teachers' teaching performance and hence, they were able to overcome any short comings of their side and increase the points of strength for more positive results. In addition, the results indicated that the practicum helped student teachers to hone their teaching skills, have sense of responsibility and commitment, and get prepared for the future teaching profession. On the contrary, student teachers were not satisfied with two issues in their teaching practicum namely; the short period of their teaching practicum and the number of the classes they taught during their practicum which was not enough. This result is due to the academic system which provides student teachers with only one-semester- training practicum. In addition, perhaps student teachers were not given as many classes as they wish because there were few classes in some schools and thus, the opportunity was not rich for student teachers.

The results of this study are consistent with those of Capan \& Bedir (2019), Hamidi et al, (2014), Nguyen (2013), Lateh \& Muniandy,(2013) and Al Sobhani (2012) where student teachers had positive perceptions of their practicum as a result of the improvement of their teaching skills, interactions and communication with their students, handling their problems, developing their classroom management skills and bridging the gap between theory and practice.

\section{Conclusions \& Implications}

This study explored the perceptions of the Saudi EFL female student teachers of four major components of their practicum namely; cooperating teachers, university supervisors, host schools and their practicum in general. The findings revealed that student teachers had a successful teaching practicum in terms of developing their teaching 
skills, knowing their students better, getting opportunities to solve their students' problems and being able to overcome such problems. In addition, student teachers had positive experiences in terms of knowing people in the host school with whom their future job will be, demonstrating an ample level of awareness of the concepts related to their practicum such as written and oral feedback, classroom management, questioning skills, brainstorming, lesson planning, motivation, teaching strategies, knowing their own points of strength and weakness. It was also obvious that the use of new technologies (i.e., exchange phone number, email addresses, Facebook and WhatsApp application) outside school hours facilitated exchanging ideas between student teachers and their cooperating teachers in terms of planning their lessons, knowing any sudden change in school timetable and sharing practicum related-ideas.

Moreover, this study recommends that student teaching practicum will be more fruitful if it is extended to one more semester so that student teachers get better opportunities for developing their teaching experience and be more aware of the processes of teaching. On the other hand, the findings of this study illustrated some valuable suggestions that need to be considered by school principals, cooperating teachers and university supervisors. For instance, student teachers need to be asked about their needs in terms of developing their practicum in the light of the up-to date strategies, new trends and methods of teaching. In addition, some student teachers are shy to get feedback from cooperating teachers and university supervisors collectively. In this respect, it might be much better if student teachers' desires are known if they prefer a collective or private feedback. This will help them share their ideas freely and frankly. Finally, the findings of this 
study call for using a specific rubric in evaluating student teachers' performance. Such rubrics should be shown to student teachers before they start their teaching practicum to give them more awareness of how they are going to be evaluated.

\section{References}

- Ahmed, A. (2014). Report Sounds Alarm Bells over Education Crisis, Calls for Reform. http://www.dawn.com/news/ 1118214. Retrieved on Nov. 12, 2018.

- Ali, H. I. H. \& Al-Adawi, H.A. (2013). Providing Effective Feedback toEFL Student Teachers. Higher Education Studies, Vol. 3.No. 3,pp. 21-35.

- Alkhawaldeh, A. H. (2008). The Reflections of Jordanian EFL Student Teachers on their Instructional Accomplishments in the Practical Education Programme. Damascus University Journal, Vol.24, No 1, pp. 29-58.

- Al-Mekhlafi, A. A. (2010). Student Teachers' Perceptions on the Effectiveness of Practicum and Practicum Supervisors. Ajman University Network of Science and Technology Journal. Vol. 15, Issue 2, 2010, pp. 7-28.

- AlSabti, K. (2012). The Role of the Ministry of Education in the Transformation to Acknowledge Based Society. Paper Presented in The Saudi International Space and Aeronautics Technology Conference 2012, and the $25^{\text {th }}$ Planetary congress of the Association of Space Explorers, Riyadh, Nov.2012. http:// www .kacstae-rosp ace.org2012/en/images/speakers/pdf/4-Al-Sabti.Pdf. Retrieved on Nov. 12. 2014.

- Al-Seghayer, K. (2014). The Actuality, Inefficiency, and Needs of EFLTeacher-preparation Programs in Saudi Arabia. International Journal of Applied Linguistics \& English Literature. Vol. 3, No. 1, pp. 143-151.

- Al Sobhani, Y. A. (2012). Prospective Teachers' Perceptions of the Teaching Practice Experience at AUST. Arab World English Journal, Vol. 3, No. 4, pp. 195-213.

- Ambrosetti, A. (2010). Mentoring and Learning to Teach: What Do Pre-Service Teachers Expect to Learn from their Mentor Teachers?. International Journal of Learning, Vol.17, No.9,pp. 117-132.

- Anderson, D. (2007). The Role of Cooperating Teachers' Power in Student Teaching, Education, Vol. 128,No. 2, pp.307-323. 
- Angell, A. (1998). Learning to Teach Social Studies. A Case Study of Beliefs Restructuring. Theory and Research in

Social Education. Vol. 26, No.4, pp. 509-529.

- Bain, J. D., Mills, C., Ballantyne, R. and Packer, J. (2002).Developing Reflection on Practice through Journal Writing: Impacts of Variations in the Focus and Level of Feedback. Teachers and Teaching: Theory and Practice, Vol. 8, No. 2, pp. 171-196.

- Ball, D. L. \& Forzani, F. M. (2009). The Work of Teaching and the Challenge for Teacher Education. Journal of Teacher Education. Vol. 60, No. 5, pp. 497-511.

- Ball, D. L., \& Thames, M. H., \& Phelps, G. (2008). Content Knowledge for Teaching: What Makes it Special? Journal for Teacher Education, Vol. 59, No. 5, pp. 389-407.

- Banabdelrahman, A. A. (2004). Roles of Cooperating Teachers and Practicum Supervisors and their Effect on EFL Studentteachers' Teaching Skills. Asian EFL Journal, Vol. 6, June 2004, Issue 3, (pages are not available).

- Barnes, M. (2013). Reflective Processes: A Qualitative Study Exploring Early Learning Student Teacher Mentoring Experiences in Student Teaching Practicum. Unpublished Ph.D. Dissertation, College of Professional Studies, Northeastern University, Boston, Massachusetts, USA.

- Beck, C. \& Kosnik, C. (2002). Components of a Good PracticumPlacement: Student Teacher Perceptions. Teacher Education Quarterly, Vol,29, No. 2, pp. 81-98.

- Burger, K. (2010). How Does Early Childhood Care and Education Affect Cognitive Development? An International Review of the Effects of Early Interventions for Children from Different Social backgrounds. Early Childhood Research Quarterly, 25, pp.140-165.

- Çapan, S. A.\& edir, H. (2019). Pre-service Teachers' Perceptions of Practicum through Reciprocal Peer Mentoring and Traditional Mentoring. Journal of Language and Linguistic Studies. 15(3), pp. 953-971.

- Carter, K. B. \& Scruggs, T. E. (2001). Thirty-one Students: Reflections of a First-year Teacher of Students with Mental Retardation. Journal of Special Education, 35, pp. 100-104.

- Coç, E.M. (2011). Factors Affecting Student Teachers' Perceptions on Mentor Roles: A Study at Distance English Language Teacher Training Program.TOJET: The Turkish Online Journal of Educational Technology. Vol. 10, No. 1, pp. 115-124. 
- Conderman, G. \& Stephens, J. T. (2000).Reflections from beginning special educators. Teaching Exceptional Children, Vol. 33, No.1, pages 16-21.

- Cruickshank, K., \& Westbrook, R. (2013). Logical and globalConflicting Perspectives? The Place of Overseas Practicum in Pre Service Teacher Education. Asia-Pacific Journal of Teacher Education, Vol. 41, No. 1, pp. 55-68.

- Cuenca, A. (2010). Care, Thoughtfulness, and Act: A Conceptual Framework for University Supervisors. Teaching Education, Vol.21, No. 3, pp. 263-278.

- Damar, E. A. (2013). ELT Teacher Trainees' Reflective Feedback to their Cooperating Teachers. Journal of Educational and Social Research, Vol. 3, No. 7, pp. 235- 242.

- Dang, T. K. A. (2013). Identity in Activity: Examining Teacher Professional Identity Formation in the Paired- placement of Student Teachers. Teaching and teacher Education, Vol. 30, pp. 47-59.

- Dobler, E., K., Kramer. C., Resnik, R. \& Devin, M.L. (2009).A Collaborative Model for Developing Classroom Management Skills in Urban Professional Development School Settings. School- University Partnerships, Vol.3 No.1, pp. 54-68.

- Dweikat, K. A. (2013). Attitudes of TEFL Student Teachers at QOU towards the Implementation of Practicum. Al-Quds University Journal for Educational \& Psychological Research \& Studies, Vol. 1, No. 3, October 2013, pp. 11- 44.

- Dyatay, D. (2007). Beginning Teacher Efficacy and the Practicum in an EFL Context. Teacher Development, Vol.11, No. 2, July 2007, pp. 203-219.

- Elyas, T. \& Richard, M. (2013). Critiquing of Higher Education Policy in Saudi Arabia: towards a New Neoliberalism. Higher Education in Saudi Arabia. Education, Business and Society: Contemporary Middle Eastern Issues, Vol. 6 No. 1, pp. 31-41.

- Fan, S. \& Le, T. (2009). ESL Pre-service Teachers: What do They Need? Paper presented at the AARE Annual Conference, Canberra. Australian Association for Research in Education.

- Farrell, T. S. (1999). Teachers Talking about Teaching: Creating Conditions for Reflection. TESL-EJ, Vo. 4, No. 2, pages 1-14. http://www. tesl-ej.org/ej14/al.html. Retrieved on Nov.14, 2014.

- Farrell, T. S. C. (2007). Failing the Practicum: Narrowing the Gap between Expectations and Reality with Reflective Practice. TESOL Quarterly, Vol. 41,No. 1, pp. 193-201. 
- Fawzi, H. \& Alddabous, S. (2019). Pre-service Teachers' Perceptions and Preferences of Feedback Process.International Journal of Education, Learning and Development. Vol.7, No.1, pp.36-47, January 2019.

- Flores, M.A., \& Day, C. (2006). Contexts which Shape and Reshape New Teachers' Identities: A Multi-Perspective Study. Teaching and Teacher Education, Vol. 22, Issue 2, February 2006, pp.219-232.

- Fullan, M. (1998). Education reform: Are we on the right track?Canadian Education Association, Vol. 38, No. 3, pp.1-7.

- Gall, M., Borg, W., \& Gall, J. (1996). Educational Research: An Introduction, $\left(6^{\text {th }}\right.$ ed $)$. Longman, USA.

- Hamaidi, D., Al-Shara, I., Arouri, Y., \& Abu Awwad, F. (2014).Student-Teachers' Perspectives of Practicum Practices and Challenges. European Scientific Journal, May 2014, Vol. 10, No. 13, pp. 191-214.

- Harter, S. (1997). The Personal Self in Social Context: Barriers to Authenticity. In R. D. Ashmore \& L. Jussim (Series Eds.), Rutgers Series on Self and Social Identity: Vol. 1. Self and identity: Fundamental Issues.(Pp.81-133).Cary,NC: Oxford University Press.

- Hascher, T., Cocard, Y. \& Moser, P. (2004). Forget about TheoryPractice is all? Student Teachers' Learningin Practicum.Teachers and Teaching: Theory and Practice, Vol. 10, N0. 6, pp. 623-637.

- Hudson, P. B. (2004). Specific Mentoring: A Theory and Modelfor Developing Primary Science Teaching Practices. European Journal of Teacher Education, Vol. 27, No. 2, pp. 139146.

- Ibrahim, M. M. A. (2008). The Role of EFL Cooperating Teachers in Supervising Student Teacher Trainees in their Practicum. Paper presented in Qatar TESOL, "Towards Excellence in the Classroom"College of the North Atlantic,Doha,Qatar,11-12/ April 2008.

- Ilin, G. (2014). Practicum from the ELT student-teachers' Eye: Expectations and Gains. International Journal of Language Academy, Vol. 2, No. 1, pp. 191-207.

- Ishihara, N. (2005). Intercultural Challenges and Cultural Scaffolding: The Experience of a Nonnative English- Speaking Student Teacher in a Us Practicum in Second Language Teaching. In M. Bigelow \& C. Walker (Eds.), Creating Teacher Community:Selected Papers from the Third International Conference on Language TeacherEducation,pp.153-173. 
Minneapolis, MN: Center for Advanced Research on Language Acquisition.

- Johnson, A. V. (2013). Early Childhood Education Practicum Students' Perceptions of their Practicum Setting and Factors Linked to Satisfaction and Teacher Efficacy. Unpublished M. A. Theses in Education, the Faculty of the Graduate School at Greensboro,North Carolina, USA.

- Jr, R. L. K. (1990). Four Decades of Calls for Reform of Teacher Education: The 1950s through 1980s.Teacher Education Quarterly, Vol. 17, No. 4, pp. 23-64.

- Kiggundu, E. \& Nayimuli, S. (2009). Teaching Practice: A Make or Break for Student Teachers. South African Journal of Education, Vol. 29, No. 3, pp. 345-358.

- Kilgore, K. L., Griffin, C. C., Otis-Wilborn, A., \& Winn, J. (2000).The Socialization of Beginning Special Educators:

Exploring their Accomplishments, their Problems, and the Influence of Context. Paper presented at the annual meeting of the American Educational Research Association. San Francisco. CA.

- Koerner,M.(1992).The Cooperative Teacher:An Ambivalent Education, Vol. 43, No. 1, pp. 46-56.

- Korthagen,F.,Loughran,J.\&Russel,T.(2006).DevelopingFundamen tal Principles for Teacher Education Programs and Practices. Teaching and Teacher Education, Vol. 22, No.8, pp. 1020-1041.

- LaBoskey, V. K. \& Richert, A. E. (2002). Identifying Good Student Teaching Placements: A Pro- Grammatik Perspective. Teacher Education Quarterly, Vol. 29, No. 2, pp. 7-34.

- Lampert,M.(2005).PreparingTeachers for Ambitious Instructional Practices: Learning to Listen and Construct and Appropriate Response. Paper presented at the annual meeting of the American Educational Research Association.

- Lateh, H. \& Muniandy, P. (2013). Pre-service Teachers' Attitudestowards Teaching Environmental Education (EE) during Practicum in Malaysian Primary Schools. Journal of Environmental Protection, Vol.4, No.2, 2013, pp. 201- 204.

- Le, R. \& White, B. (2000). Email Supervision in the Practicum: What do Student Teachers Think? Paper presented at the British Educational Research Association Annual Conference, CardiffUniversity,September7-102000.http://www.leeds.acuk/ educol /documents/00001515. htm. Retrieved on October 28, 2014.

- Liaw, E. (2014). Teacher Efficacy of Pre-service Teachers in Taiwan: The Influence of Classroom Teaching and Group Discussions. Teaching and Teacher Education. Vol. 25, Issue 1, January 2010. Pp. 176-180. 
- Liou, H. C. (2001). Reflective Practice in a Pre-service Teacher Education Program for High School English Teachers in Taiwan ROC. System, Vol. 29, No. 2, pp. 197-208.

- Mastropierim M. A. (2001). Introduction to Special Issue: Is the Glass Half Full or Half Empty? Challenges Encounteredby Firstyear Special Education Teachers. Journal of Special Education, 35,pp. 66-74.

- Maxwell, K. L., Lim, C-I., \& Early, D. M. (2006). Early Childhood Teacher Preparation Programs in the United States: National Report. Chapel Hill, NC: The University of North Carolina, FPG Child Development Institute.

- McDonald, V., \& Speece, D. L. (2001). Making Time: A Teacher's Report on her First-year of Teaching Children with Emotional Disabilities. Journal of Special Education, 35, pp. 84-91.

- McDonald, L. (2004). Effective Mentoring of Student Teachers: Attitudes, Characteristics and Practices of Successful Associate Teachers within a New Zealand Context. New Zealand Journal of Teachers' Work, Vol.1, No. 2, pp.85-94.

- Merc, A. (2010). Self-reported Problems of Pre-service EFL Teachers throughout Teaching Practicum. Anadolu University Journal of Social Sciences, Vol. 10, No. 2, pp. 199-226.

- Moody, J. (2009). Key Elements in a Positive Practicum: Insights from Australian Post-Primary Pre-Service Teachers. Irish Educational Studies, V. 28, N. 2, pp. 155-175.

- Mudzielwana,N.P.(2014).Exploring the Roles and Responsibilities of Mentors during Teaching Practice Session. Mediterranean Journal of Social Sciences. Vol. 5, No. 20, pp. 1833-1839.

- Nguyen, H. T. M. \& Jr. R. B. B. (2010). Effective peer mentoring for EFL Pre-service Teachers' Instructional Program Practice. The Asian EFL Journal Quarterly, Vol. 12, Issue 3, pp. 40-61.

- Nguyen, H. T. M. (2013). Peer Mentoring: A Way Forward for Supporting Preservice EFL Teachers Psychosocially during the Practicum. Australian Journal of Teacher Education, Vol.38, No.7, pp. 31-44.

- Ozgun-Koca, A. \& Sen, A. (2006) The Beliefs and Perceptions of Pre- service Teachers Enrolled in a Subject Area Dominant

Teacher Education Program about Effective Education', Teaching and Teacher Education, 22(7), pp. 946-960.

- Qazi , W., Rawat, K. \& Thomas, M. (2012). The Role of Practicum in Enhancing Student Teachers' Teaching Skills. American Journal of Scientific Research, Issue 44, pages 44-57. 
School of Education, University of Wisconsin-Madison (2012).Student teaching handbook.http:// www. education. wisc. edu/docs/soe-documents/student teaching handbook-summer2012.pdf?sfvrsn=2.Retrieved on Oct.26, 2020.

- Ralph, E. G. (2005). Factors Affecting Teacher-candidates' Practicum Evaluations. Journal of Teaching andLearning, Vol.3, No. 2, pp. 29-46.

- Richards, J.C.andFarrell,T.S.C. (2005). Professional Development for Language Teachers. Cambridge: Cambridge University.

- Rots, I., Aelterman, A., Vlerick, P. \&Vermeulen, K. (2007). Teacher Education, Graduates'Teaching Commitment and Entrance into the Teaching Profession. Teaching and Teacher Education, Vol. 23, No. 5, pp. 543-556.

- Siwatu, K.O. (2011). Preservice Teachers' Sense of Preparedness and Self- efficacy to Teach in America's Urban and Suburban Schools: Does Context Matter? Teaching and Teacher Education, Vol. 27, No. 2, pp. 357-365.

- Shulman, L.S. (1987). Knowledge as Teaching: Foundations of the New Reform. Harvard Educational Review, Vol.57, No. 1, pages 1-22.

- Sleep, L. (2009). Teaching to the Mathematical Point: Knowing and Using Mathematics in Teaching. Unpublished Ph.D. Dissertation, University of Michigan, Ann Arbor, USA.

- Smith, K., \& Lev-Ari, L. (2005). The Place of the Practicum in Pre-service Teacher Education. The Voice of the Students. AsiaPacific Journal of Teacher Education, Vol. 33, Issue, 3. Pp.289-302.

- Soyoung, L. (2007). Pre-service EFL Teachers' Perceptions of their Student- teaching Experiences. English Teaching, Vol. 62(4), 355-371.

- Thibeault, J. (2003). The Relationship between Student Teachers and Cooperating Teachers as a Foundation for theDevelopment of Reflective Thinking: An Exploratory Study based on Student Teachers'Perceptions Unpublished Ph.D. Dissertation, McGill University, Montreal, Canada.

- Tuli, F. \& File, G. (2009). Practicum Experience in Teacher Education, Ethiopia Journal of Educational and Sciences, Vol. 5, No. 1, pp. 107-116.

- Ulvik, M. \& Smith, K. (2011). What Characterizes a Good Practicum in Teacher Education? Education Inquiry, Vol. 2, No. 3, pages 517-536. 
Walsh, K., \& Elmslie, L. (2005). Practicum Pairs: An Alternative for First Field Experience in Early Childhood Teacher Education. Asia-Pacific Journal of Teacher Education, Vol. 33, No. 1, pp. 5-21.

- Whitebook, M., Austin, L. J. E., Ryan, S., Kipnis, F. Almaraz, M. \& Sakai, L. (2012). By Default or Design? Variations in Higher Education Programs for Early Care and Teachers and their Implications for Research Methodology, Policy, and Practice. Berkeley, CA: Center for the Studyof Child Care Employment, University of California, Berkeley.

- Wilson, E. K. (2006). The Impact of an Alternative Model of Student Teacher Supervision: Views of the Participants. Teaching and Teacher Education, Vol. 22, No.1, pp. 22- 31.

- Yan, C. \& He, C. (2010).Transforming the Existing Model of Teaching Practicum: A Study of Chinese EFL Student

Teachers' Perceptions. Journal of Educationfor Teaching.Vol. 36, No.1February 2010, pp. 57-73.

- York University (2014). MSW Practicum Manual Two (2) Year Program, A Reference guide for Students, Faculty and Field Instructors, School of Social Work, Faculty of Graduate Studies, YorkUniversity.http://www.yorku.ca/laps/sowk/ practicum/ documents/MSWPracticum Manual TwoYearProgram.pdf. Retrieved on October $2^{\text {nd }}, 2014$.

- Yuan, R. \& Lee, I. (2014). Pre-service Teachers' Changing Beliefs in the Teaching Practicum: ThreeC in an EFL Context. Elsevier Ltd,Vol.44, June2014, Pages1-12. http://www.science direct.com/science/article/pii/S0346251 X 14000244. Retrieved on Nov.9, 2014.

- Yunus, M., Hashim, H., Ishak, N. M. and Mahmoud, Z. (2010). Understanding TESL Pre-service Teachers' Teaching Experiences and Challenges vs Post-practicum Reflection form. Procedia Social and Behavioral Sciences, Vol. 9, pp. 722-728.

- Zeichner, K. (2002). Beyond Traditional Structures of Student Teaching. Teacher Education Quarterly, Vol. 2, No. 2, pages 59-64.

- Zeyrek, D. (2001). Perspectives on Professional Growth: A Study on the Diaries of Undergraduate ELT Students. Forum, Vo. 39, No. 2, pp. 8-15.

- Zheng, H. (2009). A Review of Research on EFL Pre-service Teachers' Beliefs and Practices. Journal of Cambridge Studies, Vol. 4, No. 1, pp. 73-81. 